\title{
ARAŞTIRMA/RESEARCH
}

\section{Uluslararası öğrencilerin psikolojik ve sosyokültürel süreçleri}

\author{
Psychological and sociocultural mechanisms of international students
}

\author{
Betül Dilara Şeker ${ }^{1}$, Emine Akman ${ }^{1}$
}

${ }^{1}$ Celal Bayar Üniversitesi, Fen Edebiyat Fakültesi, Psikoloji Bölümü, Manisa, Turkey

Cukurova Medical Journal 2016;41(3):504-514.

\section{Abstract}

Purpose: The aim of this to investigate the various demographic characteristics, psychological and sociocultural mechanisms of international students in accordance with adaptation variables.

Material and Methods: On the basis of the study, the associations among the psychological adaptation, sociocultural adaptation and perceived discrimination variables were examined. 187 international students from 28 different countries and six different faculties of Cela Bayar University took part as participants. Psychological adaptation examined with life satisfaction scale and sociocultural adaptation examined with Sociocultural Adaptation Scale which was adapted to Turkish in this study.

Results: The results of the study revealed that international students' psychological and sociocultural adaptation was not found to be related. On the other hand, perceived discrimination was found to be positively associated with sociocultural adaptation.

Conclusion: Psychological and sociocultural adaptation of students are not associated with each other. As students perceived discrimination level increases, they have more sociocultural adaptation difficulties.

Key words: Psychological adaptation, sociocultural adaptation, international student

\section{GİRİŞ}

Günümüzde gençlerin yurtdışında eğitim görmesi küreselleşme, iletişim ve teknoloji alanındaki gelişmelerin etkisiyle giderek daha siklıkla deneyimlenen bir durum haline gelmiştir. Yurt dışında eğitim gören öğrenci sayısı 1990 yılında yaklaşık 1,3 milyon iken, 2011 yılında bu sayının yaklaşı 4,3 milyona ulaştığ1 belirtilmektedir' ${ }^{1}$. Tüm bu gelişmelere rağmen bu sürecin psikolojik ve

\section{Öz}

Amaç: Bu çalışmada uluslararası öğrencilerin çeşitli demografik özellikleri ile psikolojik ve sosyokültürel süreçlerinin uyum değişkenleri ele alınarak incelenmesi amaçlanmıştır.

Gereç ve Yöntem: Çalışmada temel olarak psikolojik, sosyokültürel uyum ve algılanan ayrımcılık değişkenleri arasındaki ilişkiler incelenmiştir. Celal Bayar Üniversitesinin altı farklı fakülte ve birimindeki 28 farklı ülkeden gelen 187 uluslararası öğrenci çalışmada katılımcı olarak yer almıştır. Psikolojik uyum yaşam doyumu ölçeği ile sosyokültürel uyum ise bu çalışmada Türkçe'ye uyarlaması gerçekleştirilen sosyokültürel uyum ölçeği kullanılarak incelenmiştir.

Bulgular: Çalışma bulguları incelendiğinde psikolojik uyum ve sosyokültürel uyum düzeylerinin anlamlı ilişkisinin olmadığı gözlenmiştir. Öte yandan, algılanan ayrımcılığın sosyokültürel uyumda yaşanan zorlukla pozitif ilişkili olduğu bulunmuştur.

Sonuç: Öğrencilerin psikolojik ve sosyokültürel uyum düzeylerinin ilişkili değişkenler olmadığ1 ve öğrencilerin algılanan ayrımcılık düzeyi arttıkça daha fazla sosyokültürel uyum zorluğu yaşadıkları sonucuna varılmıştır.

Anahtar kelimeler: Psikolojik uyum, sosyokültürel uyum, uluslararası öğrenci

sosyolojik birçok problemi de beraberinde getirdiği düşünülmektedir². Bu deneyimler kişilerin kültürel, sosyal, psikolojik ve akademik anlamda gelişmesini sağlarken, yeni bir ülkeye ve üniversiteye başarılı şekilde uyum sağlamak psikolojik süreçler bakımından ek bir çaba gerektirir. Uluslararası öğrencilerin psikolojik süreçleri, üniversite eğitiminin getirdiği akademik stres ve yeni bir ülkeye yerleşmenin sonucu oluşan kültürel değişimin baskısından etkilenebilir. Uluslararası öğrenciler

Yazıșma Adresi/Address for Correspondence: Dr. Betül Dilara Şeker, Celal Bayar Üniversitesi, Fen Edebiyat Fakültesi, Psikoloji Bölümü, Manisa, Turkey, E-mail: dilaraseker@hotmail.com

Geliş tarihi/Received: 29.01.2016 Kabul tarihi/Accepted: 23.02.2016 
dünyadaki farklı ülkelerine daha iyi bir eğitim firsatları elde etmek ve iş firsatları yakalamak gibi çeşitli sebeplerle geçici ya da kalıcı göç etmektedir. Ancak akademik nedenler için gerçekleştirilen göç eylemi beraberinde kültürel farklılıklar ve iletişim güçlükleri gibi çeşitli psikolojik ve sosyolojik sorunlar1 da beraberinde getirmektedir. Uluslararası öğrenciler yeni geldikleri toplumda onlara yol gösterecek bilgilerin eksikliği nedeni ile yüksek düzeyde stres yaşayan gruplara benzer şekilde değerlendirilirler.

Uluslararası öğrencilerin akademik ya da sosyal bağlamda yaşadıkları güçlüklerin önemli bir nedeni olarak dil yetersizliği görülmektedir ${ }^{3}$. Uluslararas1 ögrenciler dil sorununun yanında psikolojik, sosyal ve ekonomik sorunlar da yaşayabilirler. $\mathrm{Bu}$ öğrenciler yeni bir ülkede yaşama ve bu kültüre uyum sağlama sürecinde dolayısıyla daha yalnız, daha güvensiz hissedebilir ve yeni kültürel bağlamda davranışlarını işlevsiz olarak algıllayabilirler.

Öğrencilerin akademik sorunların yanı sıra ekonomik sorunlar, sağlı hizmetlerine ulaşımda zorluklar, yalnızlık ve kişiler arası çatışma yaşadıkları bilinmektedir. $\mathrm{Bu}$ süreç özellikle kendi kültürlerinden ayrılan uluslararası öğrenciler için gittikleri ortama uyum sağlama konusunda yeni mücadele alanları ortaya çıkarır. Uluslararası öğrencilerin yaşadıkları sorunları inceleyen çeşitli araştırmalar dile dayalı, bürokratik, ekonomik, psikolojik ve sosyo-kültürel sorunlar yaşadıklarını ortaya koymuştur ${ }^{4,5}$. Yükseköğretim kurumunun Türkiye üniversitelerindeki uluslararası öğrenci istatistiklerine göre 2014 yllı itibarı ile Türkiye'deki uluslararası öğrenci sayısının 48.175 olduğu bilinmektedir (bkz. Yüksek Öğretim Kurumu 2014).

Türkiye üniversitelerine öğrenim görmeye gelen uluslararası öğrencilerin yaşadığı problemlerle ilgili çok sayıda araştırma bulunmasına rağmen, bu çalışmaların sadece yaşanan sorunları betimleyen, dil yetersizliği, ekonomik, sosyo-kültürelve kişisel uyum sorunlarının ve bunların öğrencilerin akademik başarıları üzerindeki etkisini ortaya koyan sosyodemografik çalışmalar olduğu gözlenmiştir ${ }^{2,5,6}$. $\mathrm{Bu}$ çalışma, uluslararası öğrencilerin psikolojik ve sosyokültürel süreçlerini göçün etkileri incelenirken üzerinde sıkça durulan uyum kavramı bağlamında incelemeyi amaçlamaktadır. Psikolojik ve sosyokültürel süreçler öğrencilerin psikolojik ve sosyokültürel uyumları olarak iki ayrı çerçevede ele alınacak ve bu iki farklı kavramın birbiri ile ilişkisinin ortaya konulması amaçlanmaktadır.
Bireylerin yaşamındaki değişimleri ve bu değişimler sonucu stres düzeylerini arttıran önemli durumlardan birinin de göç süreci olduğu bilinmektedir. Bireyler bir yere gittiklerinde yeni yerleştikleri yere uyum sürecine girerler. Göçmenler, mülteciler ve uluslararası öğrenciler gibi yer değiştiren farklı gruplar için bu değişim süreci ve onunla bağlantılı stres sık karşılaş1lan bir durum olarak yaşanmaktadır ${ }^{7}$. Yaşanan stres, bu gruplara ait başa çıkma süreçlerini, psikolojik iyi olma durumlarını ve uyum süreçlerini etkilemektedirr ${ }^{8}$. Genel anlamda uyum, birey ve yaşadığı çevre arasındaki uygunluğun bir ölçütü olarak kabul edilmektedir. Uyum, kişilerin karşılaştıkları yeni çevre ile uzlaşarak belirli davranışları benimsemedir. Kişiler, yeni geldikleri yere biyolojik, psikolojik, sosyal ve ekonomik farklı boyutlarda uyum sağlamaktadır

Uyum süreci açıklanırken; stres ve başa çıkma ile kültürel öğrenme kuramları temel alınmaktadır. Göçün bir sonucu olarak yaşanan uyum süreci psikolojik uyum ve sosyokültürel uyum olarak iki ayrı bakış açısına göre değerlendirilir ${ }^{9-11}$. Bireyler yeni yerleştikleri yerde çeşitli uyumsuzluklar deneyimleyebilir ve bu uyumsuzluklar stres kaynağ1 oluşturabilir. Psikolojik uyum da bu stresle başa çıkma becerisi olarak ifade edilmektedir ${ }^{12}$. Bir diğer ifade ile psikolojik uyum, bireyin yeni kültürel bağlamda kişisel ve kültürel kimliğini açıkça ortaya koyabilmesi ile bağlantılı psikolojik ve fiziksel durumunu, genel olarak psikolojik iyi olma durumunu belirtir ${ }^{13}$. Kültürel öğrenme teorisine dayanan sosyokültürel uyum ise kişinin yeni gittiği kültüre dahil olma sürecinde yaşadığ1 güçlük düzeyine göre uyumun davranısssal yönünü kapsar. Alan yazında psikolojik uyum, psikolojik iyi olma, yaşam doyumu, benlik saygisı, psikolojik semptomlar gibi bir çok farklı değişken kullanılarak değerlendirilmiştir ${ }^{13,14}$. Dolayısıyla psikolojik uyum kavramı kişinin fiziksel, ruhsal ve duygusal işlevlerini kapsamaktadır. Ayrıca, yaşam doyumunun kişinin psikolojik sağlık, intihar, depresyon ve uyumla yakından ilişkili olduğu bilinmektedir ${ }^{15,16}$. Psikolojik uyum en iyi şekilde stres ve başa çıkma bakış açısı ile anlaşılır10,17. Psikolojik uyum yer değiştirenlerin, duygu durumu, bilişsel algıları ve kişilik özelliği değişkenleri ile ilişkilidir?. Yer değiştiren kişiler psikolojik açıdan yeni gelinen kültürdeki yaşamından doyum sağlaması onların psikolojik uyum gösterdiğininin kanıtı niteliğindedir ${ }^{10}$. Psikolojik uyum, genel olarak kişilik, yaşamdaki değişimler, başa çıma şekilleri ve sosyal destek gibi 
durumlardan etkilenen psikolojik ve duygusal iyi olma olarak tanımlanmaktadır ${ }^{18}$.

Psikolojik uyumun göstergelerinden olan yaşam doyumu, bireyin yaşam alanlarını öznel değerlendirmesidir. Yaşam doyumu kavramı; bireyin şu anki, geçmişteki ve gelecekteki yaşamından doyumunu kapsar. Bir bütün olarak yaşamın genel ve bilişsel değerlendirmelerini içeren yaşam doyumu uyumsal, duygusal ve davranısssal başa çıkma tepkilerinin göstergelerinden biridir ${ }^{15}$. Genel olarak yaşam doyumu, hem öznel hem de yaşam olaylarının tümüne yönelik bir değerlendirme olarak ifade edilebilir. Bu bağlamda değerlendirildiğinde yaşam doyumunun toplumdaki tüm grupları kapsayan bir yapısı olduğu düşünülmektedir. Sağlıklı, başarılı, zengin iyi sosyal ilişkilere sahip olmak her birey tarafindan arzu edilir olsa da bu değişkenlerin yaşam doyumu üzerindeki etkisinin de kişiden kişiye farklılık gösterdiği bilinmektedir ${ }^{19}$.

Sosyokültürel uyum ise kültürel öğrenme ve sosyal yeterlilik kavramlarından etkilenen davranışsal yeterlilik olarak tanımlanır ${ }^{20}$. Sosyokültürel uyum, bireyin baskın kültürdeki bireylerle başarılı şekilde etkileşim kurabilmesine odaklanmaktadır ${ }^{10}$. Sosyokültürel uyum yeni bir kültürel çevreye uyma yeteneği ve yeni çevrenin üyeleri ile uzlaşma içerisinde bir etkileşim kurmayı ifade eder ${ }^{21}$. Genel olarak, yerel dili anlamak, arkadaş edinmek, sosyal faaliyetlerde yer almak ve okul-iş ile ilgili konuları düzenleyebilmek gibi gündelik işlevler yerine getirilmesinde yaşanan zorluk derecesi sosyokültürel uyumun ölçütü olarak görülmektedir ${ }^{22}$. Sosyokültürel uyum sağlamanın temelinde yeni gidilen sosyal çevrenin beklentilerini karşılayacak şekilde davranılması yer almaktadır.

Sosyokültürel uyum, uluslararası öğrenciler tarafından yeni kültürel norm ve değerlerin kabul edilmesini değil, daha çok kendi değerleri ile yeni değerler arasındaki farkın anlaşılmasını ve bu farklılıklarla baş etme becerisine sahip olmayı gerektirmektedir $^{9,20}$. Yapılan farklı çalışmalarda kültürel bilişsel becerilerin yüksek düzeyde psikolojik ve sosyokültürel uyum için önemli olduğu, özellikle yeni iş-eğitim çevresinde daha iyi performans becerilerinin, ortaya çıkmasını sağladığı ve psikolojik süreçleri olumlu yönde etkilediği görülmüştür ${ }^{23,24}$. Bireyin yeni yerleştiği yerde kültürel özelliklerini devam ettirmesi ve yeni yerleştiği kültürün özellikleri ile temas halinde olması halinde bireylerin psikolojik ve sosyokültürel uyum düzeylerinin daha yüksek olduğu gözlenmiştir ${ }^{25}$.
Çoklu yönlü, karmaşık bir durum olan göç sürecinde ayrımcılık yaşanabilir. Ayrımcılık, grupta değersiz olarak görülen üyelere karşı gerçekleştirilen davranışlardır ${ }^{26}$. Ayrımcılık kavramı, ayrımcılık davranışına maruz kalan bireylerin ayrımcılık ifade eden davranışları algılama düzeyini ifade eden öznel değerlendirmelerdir. Göç süreçlerinde bireylerin algıladıkları ayrımcılığın psikolojik iyi olma ve yaşam doyumları üzerinde olumsuz yönde etkili olduğu bilinmektedir ${ }^{16,26}$. Farklı etnik ve kültürel gruplardan ögrencilerin farklı seviyelerde ayrımcılık algıladıkları ya da deneyimledikleri bilinmektedir ${ }^{24}$. Uluslararas1 öğrenciler tarafindan deneyimlenen ya da algilanan ayrımcılık ögrrencilerin psikolojik süreçlerine zarar verici nitelikte olabileceği düşünülmektedir. Çünkü yüksek düzeyde algılanan ayrımcıllğın uluslararası öğrencilerin benlik saygılarını azalttığ $1^{27}$ ve psikolojik uyumu güçleştirdiği görülmüştür ${ }^{26}$.

Bu çalışmada Türkiye'de eğitim gören uluslararası öğrencilerin psikolojik ve sosyokültürel süreçleri uyum düzeyleri bağlamında incelenmiştir. Psikolojik uyum düzeyi; yaşam doyumu ölçeği, sosyokültürel uyum düzeyi ise sosyokültürel uyum ölçeği kullanılarak değerlendirilmiştir. Öğrencilerin Türkiye'deki yaşantılarının ortaya çıkardığı çeşitli uyum sorunları, psikolojik ve sosyokültürel uyum olarak iki ayrı şekilde değerlendirilmiştir. Çalışmanın amac1, Türkiye'de eğitim görmekte olan uluslararası öğrencilerin psikolojik, sosyokültürel uyumları ve bu uyum düzeylerinin birbiri ile ilişkilerinin incelenmesidir. Ayrıca sosyokültürel uyum süreçlerinin incelenmesinde kullanılmakta olan Sosyokültürel Uyum Ölçeği'nin (Sociocultural Adaptation Scale) geçerlik ve güvenirlik çalışması yapılarak Türkçe'ye uyarlanması amaçlanmıştır. Uluslararası öğrencilerin demografik özelliklerinin ortaya konulması da çalışmanın bir diğer amacıdır. $\mathrm{Bu}$ çalışma da test edilen hipotezler şu şekilde sıralanmıştır. (1) Uluslararası öğrencilerin psikolojik ve sosyokültürel uyum düzeyleri birbiriyle ilişkilidir; (2) Uluslararası öğrencilerin psikolojik ve sosyokültürel uyumları ile algılanan ayrımcılık düzeyleri ilişkilidir. Çalışmada demografik değişkenlerin uyum süreci üzerindeki etkisinin anlaşılması amaciyla cinsiyet, Türkiye ile ilgili bilgileri ve Türkiye'de okuma kararına göre uyum süreçleri de değerlendirilmiştir. Demografik özellikler ile ilgili hipotezler ise şu şekilde belirlenmiştir: (3) Türk ve akraba topluluk ülkelerinden gelen kadın ve erkek öğrencilerin psikolojik ve sosyokültürel uyum düzeyleri birbirinden farklıdır, (4) Türkiye hakkında doğrudan ve dolaylı bilgi sahibi olan Türk ve akraba 
topluluk ülkelerinden gelen öğrencilerin psikolojik ve sosyokültürel uyum düzeyleri birbirinden farklıdır, (5) Türkiye'de okuma kararı kendisi ya da başkalarına ait Türk ve akraba topluluk ülkelerinden gelen öğrencilerin psikolojik ve sosyokültürel uyum düzeyleri birbirinden farklıdır.

\section{GEREÇ VE YÖNTEM}

Bu çalışmada Manisa Celal Bayar Üniversitesi Tıp, Mühendislik, İktisadi İdari Bilimler, Fen Edebiyat Fakültesi ile Beden Eğitimi ve Spor Yüksekokulu, Uygulamalı Bilimler Yüksekokulu'nda 2015 bahar döneminde öğrenim gören 28 farklı ülkeden gelen 187 uluslararası öğrenci katılımcı olarak yer almıştır.

Katılımcıların yüzdeliklere göre sırasıyla en fazla Azerbaycan (\%42.7), Kurgizistan (\%20.3) ve Türkmenistan'dan (\%16.6) gelen öğrenciler olduğu kalan katılımciların ise diğer 25 ülkeden geldiği görülmüştür. Örneklem grubundaki katılımcıların 73' ü kadın 135' i erkektir ve yaș ortalamaları 17 ile 30 arasında $(\mathrm{X}=20.26$; $\mathrm{SS}=2.06)$ değişmektedir. Katılımcılar Manisa Celal Bayar Üniversitesi uluslararası öğrencilerinden yarı tesadüfi örneklem yöntemi ile seçilmiştir. Katılımcılara çalışmanın genel amacı ve soru formu ile ilgili gerekli açılklamalar yapılmış, katılımcılardan çalışmaya gönüllü olarak katıldıklarını belirten aydınlatılmış onam formunu doldurmaları istenmiş, katılımın gönüllülük esasına dayandığı, soru formunda isim belirtmeksizin, istenilen sorular boş bırakılarak uygulamanın gerçekleştirileceği açıklanmıştır.

Çalışma sürecinde etik standartlar göz önünde bulundurulmuş, elde edilen verilerin gizliliği ve bilimsel amaçlar dahilinde kullanılacağı ve herhangi bir yerde paylaşılmayacağ1 konusunda katılıcımlar bilgilendirilmiştir. Çalışma anket formunda, demografik değişkenlere ilişkin form, psikolojik uyumunu ölçmek amaciyla yer verilen Yaşam Doyumu Ölçeği ile sosyokültürel uyumunu ölçmek amaciyla yer verilen Sosyokültürel Uyum Ölçeği ve Algılanan Ayrımcılık Ölçeği kullanılmıştır.

\section{Demografik Bilgi Formu}

Çalışmaya katılan öğrencilerin cinsiyet, yaş, okuduğu fakülte, Türkçe bilgisi, nerede Türkçe öğrendiği, Türkiye'de okuma kararı, önceki Türkiye bilgisi, Türkiye hakkındaki bilgi kaynağ1, ne sıklıkla kendi ülkesine gittiği, gelir düzeyi, finansal destek alma, akademik başarı, Türkiye'de oryantasyon eğitimine katılma, Türkiye'de karşılaşılan sorunlar gibi bilgilerini ifade eden sorular yer almıștır.

\section{Yaşam Doyumu Ölçeği}

Ölçeğin orijinal formu bireyin yaşamına yönelik doyum düzeyini belirlemek amaciyla Diener ${ }^{28}$ tarafindan geliştirilmiş, Türkçe'ye uyarlama çalışması ise Yetim $^{29}$ tarafindan gerçekleştirilmiştir. Toplamda beş madde içeren ölçek (örn., "Yaşam koşullarım mükemmeldir") yedi dereceli puanlama ile ( $1=$ kesinlikle katılmyorum, 7= kesinlikle katıliyorum) değerlendirilmektedir. Yaşam doyumu ölçeği bireylerin kendi hayatlarına ilişkin ne derece memnuniyet hissettiklerini öznel ve genel olarak değerlendirmelerini esas alır. Ölçek maddelerinin toplam puanının yüksek olması yüksek yaşam doyumunu ifade etmektedir. Ölçeğin iç-tutarlılığını gösteren Cronbach Alpha değeri bu çalışma için 0.77 olarak bulunmuştur.

\section{Sosyokültürel Uyum Ölçeği}

Bu çalışmada sosyokültürel uyumu ölçmek amacıyla Ward ve Kennedy'nin Sosyokültürel Uyum Ölçeği kullanılmıştır ${ }^{18}$. Sosyokültürel uyum ölçeği yeni gelen grubun özelliklerine göre kolaylıkla düzenlenebilen, tutarlı şekilde geçerli ve güvenilir bulunmuş esnek

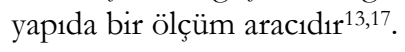

Ölçek yeni gelen katılımcıların günlük hayattaki ihtiyaçlarını karşılarken yaşadıkları zorlukları, ev sahibi toplum ile anlamlı ilişkiler kurma, ev sahibi kültürün değerlerinin anlaşılmasını kapsamaktadır. 29 maddeli ölçek "arkadaş edinmek", "kendini anlaşılır kılmak" ve "etnik ya da kültürel farklılıkları anlamak" gibi maddeleri içermektedir. Sosyokültürel uyum ölçeği beş dereceli likert tipi ölçek $(0=$ hiç zor değil, 4 = olağanüstü zor) ile değerlendirilmektedir. Ölçekten alınan yüksek puan, sosyal alanda yaşanan zorluğu ve düşük sosyokültürel uyumu ifade etmektedir ${ }^{18}$.

Ölçeğin Türkçe'ye uyarlama çalışmasında yap1 geçerliği için açıklayıcı faktör analizi uygulanmıştır. Faktör analizi uygulamasinda faktör belirleme yöntemi olarak temel bileşenler analizi, varimax döndürme işlemi kullanılmıştır. Buna göre, ölçeğin maddelerinin temel bileşenler analizi için uygunluğunun bir ölçütü olan Kaiser-Meyer-Olkin (KMO) indeksi $0.92(\mathrm{p}=.00)$ olarak-çok iyi uyum düzeyinde- bulunmuştur. Ölçeğin tek faktörlü bir yapısı olduğu ve açıklanan varyansın tek faktör ile 0.39 olduğu görülmüştür. 
Sosyokültürel uyum ölçeği zaman içinde değişme gösteren bir ölçek olduğundan ve kişilerin durağan ve değişmez özelliklerini ölçmediğinden test-tekrar test güvenirliği yöntemi bu ölçeğe uygun görülmeyerek uygulanmamıştır. Ölçek maddelerinin faktör yüklerinin 0.37 ile 0.73 arasında değiştiği bulunmuştur. Sonuçlar sosyokültürel uyum ölçeğinin Türkçe formunun faktör yapısının tek faktörden oluştuğunu göstermiştir (Ek 1). Ölçeğin Cronbach alpha değeri 0,94 olarak alanyazınla tutarlı şekilde oldukça yüksek olduğu bulunmuştur ${ }^{10,13}$. Ölçeğin madde-toplam korelasyon puanlar1 0.40 ile 0.71 arasında değişmektedir.

\section{Algılanan Ayrımcılık Ölçeği}

Bireyin ayrımcılıkla karşılaşma sıklığını ölçmek için Ruggiero ve Taylor ${ }^{30}$ tarafindan geliştirilen ölçeğin Türkçe'ye uyarlama çalışması Baysu ${ }^{31}$ tarafindan gerçekleştirilmiştir. Toplam dört maddeden oluşan ölçek (örn., "Ait olduğum kimlik grubu yüzünden kabul görmediğimi hissediyorum”) kişisel olarak algılanan ayrımcılık düzeyini ölçmektedir. Ölçek puanları beş dereceli Likert tipi ölçek ile (1 = asla, 5 = daima) değerlendirilmektedir. Ölçekten alınan yüksek puanlar yüksek düzeyde alg1lanan ayrımcıllı̆ı ifade etmektedir. Bu çalışmada bireysel ayrımcilık ölçeğine ait iç tutarlıllğ gösteren cronbach alpha değeri 0.87 olarak bulunmuştur.

\section{İstatistiksel İşlemler}

Çalışmadaki tüm veriler IBM The Statistical Package for Social Sciences (SPSS) Statistics v22 (IBM Corporation, New York, United States) paket programı kullanılarak analiz edilmiştir. Kategorik değişkenlere ilişkin veriler frekans ve yüzde değerlerini ortaya koyan tanımlayıc1 istatistik analizleri kullanılarak çözümlenmiştir. Bağımsız iki grubun sürekli değişkenlerinin ortalamalarını karşılaştırmak amacıyla Student $\mathrm{T}$ Testi kullanılmıştır. Çalışmadaki değişkenler arasındaki ilişkileri incelemek amaciyla pearson korelasyon testi uygulanmıştır.

Ayrıca sosyokültürel uyumu ölçmek amacıyla geliştirilen sosyokültürel uyum ölçeğinin Türkçe’ye uyarlanması için ölçeğin yap1 geçerliğinin değerlendirilmesi amacıyla açımlayıcı faktör analizi ve güvenirliğinin incelenmesi amaciyla madde toplam güvenirlik analizi, kullanılmıştır. Çalışmada 0.05 in altında olan $\mathrm{p}$ değeri istatistiksel olarak anlamlı kabul edilmiştir.

\section{BULGULAR}

Öğrencilerden elde edilen demografik bilgiler betimleyici istatistik analizleri uygulanarak çözümlenmiş ve elde edilen sonuçların frekans ve yüzde değerleri Tablo 1' de gösterilmiştir. Öğrencilerin Türkçe'yi nereden öğrendiklerine ait frekans analizi sonuçları incelendiğinde $\% 38.5{ }^{\prime} \mathrm{i}$ kendi çabasıyla, \%38.5'i kursa giderek ve \%13.2'ü orta öğretimde \%11.8’ ise diğer kaynaklar ile öğrendiğini belirtmiştir. Öğrencilerin Türkiye'de okuma kararının kaynağı olarak \%54'ü kendi isteği, $\% 15.5$ 'i aile etkisi, \%12.3'ü eğitimci yönlendirmesi, \%9.6's1 ülke kontenjan, \%6.4'ü arkadaş çevresi ve $\% 2.1$ 'i ise diğer sebepler gösterilmiştir. Bu öğrenciler Türkiye ile ilgili önceki bilgilerini \%36,4'ünü Türkiye'deki tanıdıklarından, \%34.2'si kendi araştırmalarından, $\% 17.7$ si diğer kaynaklardan ve $\% 11.8$ ' ise ülkesindeki tanıdıklarından edindiğini belirtmiştir. Öğrencilerin aile gelir düzeyleri yedi dereceli bir ölçekte değerlendirilmiş ve ortalama aile gelir düzeyi 3.98 (SS = 0.76) olarak bulunmuştur. Öğrencilerin 'Türkiye'deki eğitimini finanse eden kaynağa yönelik frekans analizinde ise \%64.7'si kendi ailesinin, \%18.2'si Türkiye'nin, \%11.2'si kendi ülkesinin ve \%5.8'i ise diğer kaynakların finanse ettiklerini göstermiştir. Ayrıca, öğrencilere Türkiye'de üniversite eğitimine başlarken herhangi bir oryantasyon programına dahil olup olmadikları sorulmuş ve \%71.1'inin oryantasyon kursuna katılmadığ1, \%19,8'inin ise katıldığı bulunmuştur. Tablo 1 de görüldüğü üzere, Türkiye'de yaşadıkları sorunlara ait frekans analizi sonucunda öğrencilerin \%34.2'ü en sı yaşanan sorunun kalacak yer bulma olduğunu ve \%33.2'si ise dil sorunu olduğunu belirtmiştir. Buna ek olarak öğrenciler, yemeklere alışma, güvenlik, kendini ifade ve bürokratik konularla ilgili sorunlarla da sık karşılaştıklarını belirtmişlerdir.

Öğrencilerin \%47.12’i hem Türk hem uluslararas1 öğrencilerle, \%34.7'si uluslararası öğrencilerle, \%18.2'si ise Türk öğrencilerle daha s1k arkadaşlık ettiği görülmüştür. Son olarak öğrencilere sorunlarını sıklıkla paylaştıkları kişiler sorulmuş ve \%58.8'i ailesiyle, \%23.5'i Türk öğrenci arkadaşlarılya, \%12.3’ü uluslararası öğrenci arkadaşları ile paylaştıklarını belirtmiştir. Öğrencilerin kendi ülkelerine gitme siklığ1 y1lda ortalama $1.43 \pm 0.74$ olduğu görülmüştür. Öğrencilerin kendi akademik başarılarını değerlendirme ortalamasının yedili ölçek üzerinden $4.72 \pm 0.98$ olduğu ve öğrencilerin kendilerini oldukça başarılı olarak değerlendirdiği 
görülmüş̧ür. Ayrıca öğrencilerin Türkçe bilgisine ait ortalamaları 5'li ölçek üzerinden okuma alanında
$3.94 \pm 0.86$ anlama alanında $4.02 \pm 0.84$ ve yazma alanında $4.01 \pm 0.84$ olarak bulunmuştur.

Tablo 1. Öğrencilerin demografik özelliklerine göre dağılımı

\begin{tabular}{|c|c|c|c|}
\hline Demografik Özellik & Kategori & $\mathbf{N}$ & $\%$ \\
\hline \multirow[t]{4}{*}{ Türkçe Öğrenme Kaynağ 1} & Orta ögrretimde & 25 & 13,2 \\
\hline & Kendi çabamla & 70 & 38,5 \\
\hline & Kursa gittim & 70 & 38,5 \\
\hline & Diğer & 22 & 11,8 \\
\hline \multirow[t]{6}{*}{ Türkiye’de Okuma Kararı } & Ülke Kontenjan1 & 18 & 9,6 \\
\hline & Aile Etkisi & 29 & 15,5 \\
\hline & Kendi İsteği & 101 & 54 \\
\hline & Arkadaş Çevresi & 12 & 6,4 \\
\hline & Eğitimci Yönlendirmesi & 23 & 12,3 \\
\hline & Diğer & 4 & 2,1 \\
\hline \multirow[t]{4}{*}{ Önceki Türkiye Bilgisi } & Türkiye'deki tanıdıklardan & 68 & 36,4 \\
\hline & Kendi araștırarak & 64 & 34,2 \\
\hline & Ülkesindeki tanıdıklardan & 22 & 11,8 \\
\hline & Diğer & 33 & 17,7 \\
\hline \multirow[t]{4}{*}{ Eğitimi Kimin Finanse ettiği } & Türkiye & 34 & 18,2 \\
\hline & Kendi ülkesi & 21 & 11,2 \\
\hline & Ailesi & 121 & 64,7 \\
\hline & Diğer & 11 & 5,8 \\
\hline \multirow[t]{5}{*}{ Finansal Destek } & Kamu bursu & 65 & 34,8 \\
\hline & Özel burs & 25 & 13,4 \\
\hline & Akraba desteği & 28 & 15 \\
\hline & Yakın çevre desteği & 28 & 15 \\
\hline & Diğer & 31 & 16,6 \\
\hline \multirow{2}{*}{$\begin{array}{l}\text { Oryantasyon Kursuna } \\
\text { Katılma }\end{array}$} & Evet & 37 & 19,8 \\
\hline & Hayır & 132 & 71,1 \\
\hline \multirow[t]{7}{*}{ Türkiye'deki Sorunlar } & Dil sorunu & 62 & 33,2 \\
\hline & Kalacak yer sorunu & 64 & 34,2 \\
\hline & Yemek sorunu & 19 & 10,2 \\
\hline & Güvenlik sorunu & 11 & 5,9 \\
\hline & Kendini ifade sorunu & 11 & 5,9 \\
\hline & Bürokratik sorunlar & 8 & 4,3 \\
\hline & Diğer & 12 & 6,4 \\
\hline \multirow[t]{3}{*}{ Sık arkadaşlık edilenler } & Türk öğrenciler & 34 & 18,2 \\
\hline & Uluslararası öğrenciler & 65 & 34,7 \\
\hline & Her ikisi (Türk ve uluslararası) & 88 & 47,1 \\
\hline \multirow[t]{4}{*}{ Sorunları Paylaşma } & Aile ile & 110 & 58,8 \\
\hline & Türk öğrencilerle & 23 & 23,5 \\
\hline & Uluslararası öğrencilerle & 44 & 12,3 \\
\hline & Diğer & 10 & 5,4 \\
\hline
\end{tabular}

N: Katılımcı sayısı, \%: Yüzdelik değer

Çalışmada psikolojik süreçlerin incelenmesinde uyum değişkenleri olarak ele alınan yaşam doyum, sosyokültürel uyum ve psikolojik uyum ve sosyokültürel uyum değişkenleri üzerinde etkisi olduğu düşünülen algılanan ayrımcilık arasındaki ilişkileri incelemek amacıyla korelasyon analizi uygulanmıştır. Korelasyon analizi sonucunda yaşam doyumu ile sosyokültürel uyum arasında istatistiksel olarak anlamlı bir ilişki olmadığı görülmüştür ( $\mathrm{r}=$ -
0.11, p > 0.05). Öğrencilerin yașam doyumu ile algilanan ayrımcilik arasında da istatistiksel olarak anlamlı bir ilişki olmadığı bulunmuştur $(\mathrm{r}=0.03$, p $>$ 0.05). Ancak, sosyokültürel uyum ile algilanan ayrımcilik arasında istatistiksel olarak anlamlı ve pozitif yönlü bir ilişki olduğu $(\mathrm{r}=0.43, \mathrm{p}<0.01)$ gözlenmiştir. Dolayısıyla öğrencilerin algıladıkları ayrımcılık düzeyi ile sosyokültürel uyumda zorluk yaşamanın ilişkili olduğu ortaya konmuştur. 
Bu bölümde, öğrencilerin cinsiyetlerinin, Türkiye'de okuma kararı alma konusundaki tercihlerinin ve Türkiye ile ilgili bilgileri nereden edindiklerinin psikolojik uyumları ve sosyokültürel uyumları üzerindeki etkisi incelenmiştir. Uluslararası öğrencilerin psikolojik ve sosyokültürel uyum ile algılanan ayrımcılık düzeyleri bakımından cinsiyete göre farklılık gösterip göstermediği bağımsız gruplar için $t$ testi uygulanarak değerlendirilmiştir. Yapılan bağımsız gruplar t-testi sonuçları Tablo 2'de gösterilmektedir. Öğrencilerin yaşam doyumu düzeylerinin cinsiyete göre farklılaşmadığı bulunmuştur $\left(\mathrm{t}_{(184)}=4.63, \mathrm{p}>0.05\right)$. Öte yandan, öğrencilerin sosyokültürel uyum düzeylerinin cinsiyete göre istatistiksel olarak anlaml şekilde farklılaştığ1 bulunmuştur $\quad\left(\mathrm{t}_{(184)}=2.40, \quad \mathrm{p}<0.05\right)$. Dolayısıyla, kadın öğrencilerin soyokültürel uyumlarının, erkek öğrencilerden daha düşük olduğu görülmüştür.

Uluslararası öğrencilerin psikolojik, sosyokültürel uyum ve algilanan ayrımcılık düzeyleri bakımından Türkiye'de okuma kararına göre farklılık gösterip göstermediği bağımsız gruplar için $t$ testi uygulanarak değerlendirilmiştir. Yapılan bağımsız gruplar t-testi sonuçları Tablo 2'de gösterilmektedir. Ancak, öğrencilerin yaşam doyumu düzeylerinin Türkiye'de okuma kararının kendilerinin ya da başkalarının olmasına göre farklılaşmadığ görülmüştür $\left(\mathrm{t}_{(184)}=0.40, \mathrm{p}>0.05\right)$. Ek olarak, öğren cilerin sosyokültürel uyum düzeylerinin Türkiye'de okuma kararının kendileri ya da başkaları tarafından alınma durumuna göre istatistiksel olarak anlamlı şekilde farklılaştı̆̆1 bulunmuştur $\left(\mathrm{t}_{(184)}=4.63\right.$, $\mathrm{p}<0.01)$. Buna göre, Türkiye'de okuma kararını kendisi alan öğrencilerin sosyokültürel uyum düzeylerinin, Türkiye'de okuma kararını başkaları tarafindan verilen öğrencilerden daha yüksek olduğu gözlenmiştir. Uluslararası öğrencilerin psikolojik uyum, sosyokültürel uyum ve algilanan ayrımcilık düzeyleri bakımından Türkiye'ye gelmeden önceki ülke ile ilgili bilgileri kaynaklarına göre farklılık gösterip göstermediği bağımsız gruplar için $\mathrm{t}$ testi uygulanarak incelenmiştir. Tablo 2'de belirtildiği gibi öğrencilerin yaşam doyumu $\left(\mathrm{t}_{(156)}=0.41, \mathrm{p}>0.05\right)$ ve sosyokültürel uyum $\left(\mathrm{t}_{(154)}=-0.43, \mathrm{p}>0.05\right)$ düzeylerinin Türkiye hakkındaki bilgilerini kendileri araştırarak edinmeleri ya da diğerlerinden öğrenerek edinmelerine göre anlamlı şekilde farklılaşma göstermemiştir.

Tablo 2. Öğrencilerin yaşam doyumu, sosyokültürel uyum ve algılanan ayrımcılık ğeğerlendirme ortalamaları, standart sapmaları ve $t$ değerleri

\begin{tabular}{|c|c|c|c|c|c|c|c|}
\hline & & & $\mathbf{N}$ & Ort & SS & $\mathrm{t}$ & $\mathrm{p}$ \\
\hline \multirow[t]{2}{*}{ Yaşam doyumu } & \multirow[t]{2}{*}{ Cinsiyet } & Kadin & 72 & 19.63 & \pm 5.70 & \multirow[t]{2}{*}{1.33} & \multirow[t]{2}{*}{0.19} \\
\hline & & Erkek & 114 & 18.60 & \pm 4.57 & & \\
\hline \multirow[t]{2}{*}{ Sosyokültürel uyum } & \multirow[t]{2}{*}{ Cinsiyet } & Kadın & 72 & 43.84 & \pm 21.86 & \multirow[t]{2}{*}{2.40} & \multirow[t]{2}{*}{0.02} \\
\hline & & Erkek & 114 & 36.29 & \pm 19.87 & & \\
\hline \multirow[t]{2}{*}{ Yaşam doyumu } & \multirow[t]{2}{*}{ Türkiye kararı } & Kendisinin & 101 & 18.86 & \pm 5.23 & \multirow[t]{2}{*}{0.40} & \multirow[t]{2}{*}{0.69} \\
\hline & & Diğerlerinin & 85 & 19.16 & \pm 4.84 & & \\
\hline \multirow[t]{2}{*}{ Sosyokültürel uyum } & \multirow[t]{2}{*}{ Türkiye kararı } & Kendisinin & 101 & 32.74 & \pm 17.03 & \multirow[t]{2}{*}{4.63} & \multirow[t]{2}{*}{0.00} \\
\hline & & Diğerlerinin & 85 & 46.54 & \pm 22.57 & & \\
\hline \multirow[t]{2}{*}{ Yaşam doyumu } & \multirow[t]{2}{*}{ Bilgi kaynağ1 } & Kendisi & 97 & 19.19 & \pm 5.32 & \multirow[t]{2}{*}{0.41} & \multirow[t]{2}{*}{0.69} \\
\hline & & Diğerleri & 64 & 18.86 & \pm 4.54 & & \\
\hline \multirow[t]{2}{*}{ Sosyokültürel uyum } & \multirow[t]{2}{*}{ Bilgi kaynağ1 } & Kendisi & 97 & 38.02 & \pm 21.58 & \multirow[t]{2}{*}{-0.43} & \multirow[t]{2}{*}{0.67} \\
\hline & & Diğerleri & 64 & 39.44 & \pm 18.19 & & \\
\hline
\end{tabular}

N: Katılimc1 say1s1, Ort: Ortalama, SS: Standart sapma,

\section{TARTIŞMA}

Bu çalışmada eğitim amacıyla belirli bir süre için Türkiye'ye göç eden uluslararası öğrencilerin psikolojik ve sosyokültürel süreçleri ile onlarla ilişkili değişkenler incelenmiştir. Alanyazında dezavantajlı bir grup olarak değerlendirilen ${ }^{3}$ uluslararası öğrencilerin yaşadıkları psikolojik ve sosyokültürel süreçlerin kapsamlı şekilde incelenmesi çalışmanın temel amaçlarından biridir. Psikolojik ve sosyokültürel süreçler çalışma içinde yaşam doyumu ve sosyokültürel uyum değişkenleri çerçevesinde incelenmiştir.

Ayrıca, Türkçe'ye uyarlanmış herhangi bir sosyokültürel uyum ölçeği bulunmadığından Sosyokültürel Uyum Ölçeği'nin geçerlik ve güvenirlik çalışması da gerçekleştirilmiştir Uluslararası öğrencilerin demografik özelliklerinin ortaya konulması da çalışmanın diğer amaçlarından 
biridir. Ek olarak, çalışmada psikolojik ve sosyokültürel uyum süreçlerinin algılanan ayrımcıllk kavramı ile ilişkisi de değerlendirilmiştir.

Çalışmada uluslararası öğrencilerin çeşitli demografik özellikleri incelenmiş ve katılımcıların çoğunun Türk Cumhuriyetlerinden gelen öğrenciler olduğu görülmüştür. Özellikle Türk Cumhuriyetlerinden gelen öğrencilerin Türkçe okuma, anlama ve yazma bilgilerine ilişkin öznel değerlendirmelerinin oldukça yüksek olduğu ve kendilerini Türkçe bilgisi bakımından yeterli olarak tanımladıkları gözlenmiștir. Öğrencilerin eğitim sürecinde karşılaștıklarını belirttikleri problemler içinde en sık karşılaşılan durum ise kalacak yer problemidir. İkinci sırada en sık karşılaşılan problemin ise dil yeterliliği ile ilgili olduğu görülmüştür. Öğrencilerin dil konusunda kendilerini yeterli hissetmeleri ile dili ikinci en sık karşılaştıkları sorun olarak belirtmelerinin uyuşmayan bir sonuç olduğu düşünülmektedir. Bu durumun akademik dil olarak Türkçe'nin kullanılmasından kaynaklandığ1 düşünülmektedir. Buna ek olarak öğrencilerin barınma ve dil sorununa göre daha düşük oranda karşılaştıkları sorunlar, yemeklere alışma, güvenlik, kendini ifade ve bürokratik konular olarak belirtilmiştir. Uluslararası öğrencilerle gerçekleştirilen farklı bir çalışmada da benzer şekilde çoğu öğrencinin Türkiye'ye ilk geldiklerinde yemeklere alışmakta zorlandıkları belirlenmiştir ${ }^{32}$. Çalışmada öğrencilerin çoğunun hem Türk hem uluslararası öğrencilerle daha sık arkadaşlık ettiği görülmüştür. $\mathrm{Bu}$ durumun da öğrencilerin dil yeterliliğine olumlu etkisinin olabileceği düşünülmektedir. Ward ve arkadașları ev sahibi toplum ile kurulan etkileșimin psikolojik ve sosyokültürel süreçlerde olumlu etkisi olduğunu ortaya koymuştur ${ }^{10,11,17}$. Çünkü ev sahibi kültürden bireylerle kurulan ilişkilerin yeni toplumun normlarını öğrenmenin yanında günlük yaşantıda karşılaşılan psikolojik ve sosyal problemlerin üstesinden gelmeyi de kolaylaştırdığı bilinmektedir ${ }^{24}$.

Psikolojik ve sosyokültürel uyum değişkenlerinin birbiriyle ilişkili olduğuna dair hipotezin desteklenmediği, bu değişkenlerin birbiriyle ilişkili olmadığ1 bulunmuştur. Bu durum psikolojik ve sosyokültürel süreçlerin birbirleriye ilgili olmalarına rağmen, farklı birçok faktörden etkilenmeleri ile açıklanabilir. Benzer şekilde, Ward ve Searle ${ }^{10}$ psikolojik ve sosykültürel uyumun birbiri ile ilişkili olduğunu ancak bu iki kavram arasında farklı değişkenler tarafindan yordanma ve zaman içinde farklı şekilde değişim gösterme gibi bazı farklılıklar da bulunduğunu belirtmiştir. Çalışmanın uluslararası öğrencilerin psikolojik ve sosyokültürel uyumları ile algılanan ayrımcılık düzeyleri ilişkili olduğunu belirten bir diğer hipotezinin de kısmen doğrulandığ görülmektedir. Daha önce ayrımcıllğın yaşam doyumu üzerinde olumsuz bir etkisi olduğu vurgulanmış ${ }^{33}$ olsa da bu çalışmada psikolojik uyum ile algılanan ayrımcılık arasında anlamlı bir ilişki olmadığı bulunmuştur. Sosyokültürel uyum ile algılanan ayrımcıllk arasında ise pozitif bir ilişki olduğu gözlenmiştir. Dolayısıyla, öğrencilerin sosyokültürel uyumda yaşadıkları zorluk arttıkça algıladıkları ayrımcılık durumunun da arttığ düşünülmektedir. Ayrıca alanyazında uluslararası öğrencilerin karşılaştıkları ön yarg1ların algıladıkları ayrımcılığı etkileyerek sosyokültürel uyumu zorlaştırdığını gösteren pek çok araştırma bulunmaktadir ${ }^{34-36}$.

Çalışmada ayrıca demografik değişkenlerin uyuma etkisinin anlaşılması amaciyla; cinsiyet, Türkiye ile ilgili bilgileri ve Türkiye'de okuma kararına göre oluşturulan hipotezler incelenmiştir. Kadın ve erkek öğrencilerin psikolojik süreçler bakımından arasında bir fark olmadığı, bunun yanında, kadın öğrencilerin erkek öğrencilerden daha düşük düzeyde sosyal kültürel uyuma sahip olduğu görülmüştür. Kadın ve erkeklerin farklı düzeylerde sosyo kültürel uyuma sahip olmasının temelinde, uyum sürecinde her iki cinsiyet için farklılaşan yordayıcıların etkisinin olduğu bilinmektedir ${ }^{37,38}$. Ayrıca, yurtdışından gelen öğrenci sayılarının ve aynı ülkeden gelen öğrenci gruplarının cinsiyete göre eşit olmaması nedeniyle erkek öğrencilerin grup içinde daha yüksek düzeyde sosyal destek sağladığı ve kadın öğrecilere göre daha iyi sosyokültürel uyum gösterdiği düşünülmektedir.

Türkiye ile ilgili doğrudan ya da dolaylı yoldan bilgi sahibi olan öğrencilerin psikolojik ve sosyokültürel uyum düzeyleri ile ilgili oluşturulan fark hipotezi de kısmen doğrulanarak Türkiye'de okuma kararını kendisi alan öğrencilerin sosyokültürel uyumlarının, bu kararı verirken başkalarının etkisinde olan öğrencilerden daha yüksek olduğu gözlenmiştir. Dolayısıyla kişilerin seçimlerinde aldıkları aktif rolün başa çıkma süreçleri üzerinde olumlu bir etkisi olduğu düşünülebilir. Son olarak, uluslararas1 öğrencilerin Türkiye'ye gelmeden önce kendileri ya da diğer kaynaklardan bilgi edinmelerine göre psikolojik ve sosyokültürel uyumlarının herhangi bir farklılık göstermediği gözlenmiştir. Özetle, uyum sürecinde bireyin ev sahibi toplum hakkında önceki bilgilerinin kaynağından çok, yer değiştirme kararının 
bireyin kendisi tarafindan verilmesinin etkili olduğu düşünülmektedir.

Bu çalışmanın alanyazına sağladığı katkılardan biri de sosyokültürel uyum ölçeğinin Türkçe'ye uyarlama, geçerlik ve güvenirlik çalışmasının gerçekleştirilmesidir. Sosyokültürel uyum ölçeği misafir grubun özelliklerine göre kolaylıkla düzenlenebilen, birçok farklı kültürde geçerli ve güvenilir bulunmuş esnek yapıda bir ölçüm aracıdır ${ }^{13,17}$. Ölçeğin Türkiye'deki hareketli gruplara (göçmen, mülteci, uluslararası öğrenci vb.) uygulanabilecek kısa, anlaşılır ve açık bir yapısı olduğundan uygulamalar sirasinda dil sorununu en az seviyeye indireceği düşünülmektedir. Ek olarak, çalışma sonuçlarının uluslararası öğrencilerin psikolojik ve sosyokültürel uyum süreçlerine dikkat çekerek alanyazına katkı sağlayacağı düşünülmektedir. Uluslararası öğrenci grubunun ev sahibi topluluktan ya da farklı grup ögrrencilerle karşılaştırılmamış olması çalışmanın bir sınırlılı̆̆ olarak görülebilir. Ek olarak, katılımcıların Türkiye'de yaşama sürelerine göre homojen olmayan uluslarararası öğrencilerden oluşması diğer bir sınırlılık olarak düşünülebilir. Ayrıca katılımcıların çoğunun Türk Cumhuriyetlerinden gelen ögrencilerden oluşması, çalışma bulguları üzerinde etkili olabileceğinden bir diğer sinırlılık olarak ele alınabilir. Yapılan çalışmanın uluslararası öğrencilerin psikolojik ve sosyokültürel süreçlerinin anlaşılarak uyumlarının kolaylaştırılması ve ihtiyaçlarının karşılanması için farklı düzenlemeler yapılması açısından önemli olduğu düşünülmektedir.

\section{KAYNAKLAR}

1. OECD. Education indicators in focus. 2013;05(April):1-4. Available from: http://www.oecd.org/education/skills-beyondschool/EDIF 2013--N\%C2\%B014 (eng)-Final.pdf (Accessed at 27.01.2016)

2. Ergin G, Türk F. Türkiye'de öğrenim gören orta asyalı öğrenciler. Sosyal ve Beşeri Bilimler Dergisi. 2010;2:35-41.

3. Cakir SG. Ego identity status and psychological wellbeing among Turkish emerging adults. Identity: An International Journal of Theory and Research. 2014;14:230-9.

4. Kashima ES, Loh E. International students' acculturation: effects of international, conational, and local ties and need for closure. Int J Intercult Relations. 2006;30:471-85.

5. Kılıçlar A, Sarı Y, Seçilmiş C. Türk dünyasından gelen öğrencilerin yaşadıkları sorunların akademik başarılarına etkisi: turizm öğrencileri örneği. Bilig. 2012;61:157-72.

6. Otrar M, Ekşsi H, Dilmaç B, Şirin A. Türkiye'de öğrenim gören Türk ve akraba topluluk öğrencilerinin stres kaynakları, başaçıkma tarzları ile ruh sağllğı arasındaki ilişki üzerine bir araştırma. Kuram ve Uygulamada Eğitim Bilimleri. 2002;2:47799.

7. Yakushko O, Watson M, Thompson S. Stress and coping in the lives of recent immigrants and refugees: considerations for counseling. Int $\mathrm{J}$ Adv Couns. 2008;30:167-78.

8. Kuo BCH. Coping, acculturation, and psychological adaptation among migrants: a theoretical and empirical review and synthesis of the literature. Heal Psychol Behav Med. 2014;2:16-33.

9. Oguri M, Gudykunst WB. The influence of self construals and communication styles on sojourners' psychological and sociocultural adjustment. Int J Intercult Relations. 2002;26:577-93.

10. Ward C, Searle W. The impact of value discrepancies and cultural identity on psychological and sociocultural adjustment of sojourners. Int J Intercult Relations. 1991;15:209-24.

11. Yang RP-J, Noels KA, Saumure KD. Multiple routes to cross-cultural adaptation for international students: mapping the paths between self-construals, English language confidence, and adjustment. Int J Intercult Relations. 2006;30:487-506.

12. Abu-Rayya H. Psychological and socio-cultural adaptation of immigrant and national adolescents in Australia: a test of the acculturative stress hypothesis. Am J Appl Psychol. 2013;2:1-6.

13. Ward C, Kennedy A. Acculturation and crosscultural adaptation of British residents in Hong Kong. J Soc Psychol. 1993;133:395-7.

14. Berry J, Phinney J, Sam D, Vedder P. Immigrant youth: Acculturation, identity, and adaptation. Appl Psychol. 2006;55:303-32.

15. Diener E, Ryan K. Subjective well-being: a general overview. South African J Psychol. 2009;39:391-407.

16. Jasperse M, Ward C, Jose PE. Identity, perceived religious discrimination, and psychological well-being in muslim immigrant women. Appl Psychol. 2012;61:250-71.

17. Searle W, Ward C. The prediction of psychological and sociocultural adjustment during cross-cultural transitions. Int J Intercult Relations. 1990;14:449-64.

18. Ward C, Kennedy A. The measurement of sociocultural adaptation. Int J Intercult relations.1999;23:659-77.

19. Diener E. Subjective well-being. The science of happiness and a proposal for a national index. Am Psychol. 2000;55:34-43.

20. Berry J, Ataca B. Cultural factors in stress. In: Encyclopedia of Stress. Vol. I (Ed. G Fink):604-11. San Diego, CA, Academic Press; 2000.

21. Ward CRF. Personality, cultural intelligence, and 
cross-cultural adaptation. In: Handbook of cultural intelligence (Ed SLVD Ang):159-73. M.E. Sharpe. 2008.

22. Berry J. Acculturation: Living successfully in two cultures. Int J Intercult relations. 2005;29:697-712.

23. Earley PC, Ang S. Cultural Intelligence: Individual Interactons Across Cultures. Stanford, Stanford University Press, 2003.

24. Ying $\mathrm{Y}$, Lee $\mathrm{P}$ a, Tsai JL. Cultural orientation and racial discrimination: predictors of coherence in Chinese American young adults. J Community Psychol. 2000;28:427-41.

25. Matsumoto D. The Handbook of Culture and Psychology. New York, Oxford University Press, 2001.

26. Virta E, Sam DL, Westin C. Adolescents with Turkish background in Norway and Sweden: a comparative study of their psychological adaptation. Scand J Psychol. 2004;45:15-25.

27. Schmitt M. Constructing a minority group identity out of shared rejection: the case of international students. Eur J Soc Psychol. 2003;33:1-12.

28. Diener E, Horwitz J, Emmons R. Happiness of the very wealthy. Soc Indic Res. 1985;16:263-74.

29. Yetim Ü. Life satisfaction: A study based on the organization of personal projects. Soc Indic Res. 1993;29:277-89.

30. Ruggiero K, Taylor D. Coping with discriminationhow disadvantaged group members perceive the discrimination that confronts them. J Pers Soc Psychol. 1995;68:826-38.

31. Baysu G. The Effects of Intergroup Perceptions and Ingroup Identifications on the Political Participation of the Second-Generation Turkish Migrants in the Netherlands. Ankara, Middle East Technical University; 2007.

32. Kıroğlu K, Kesten A, Elma C. Türkiye'de öğrenim gören yabancı uyruklu lisans öğrencilerinin sosyokültürel ve ekonomik sorunlar1. Mersin Üniversitesi Eğitim Fakültesi Dergisi. 2010;6:26-39.

33. Utsey S, Payne Y. Race-related stress, quality of life indicators, and life satisfaction among elderly African Americans. Cult Divers Ethn Minor Psychol. 2002;8:224-233.

34. Mori SC. Addressing the mental health concerns of international students. J Couns Devel. 2000;78:13744.

35. Șeker B, Akman E. Farklı ülkelerden üniversite öğrencilerinin psikolojik iyi olma ve yaşam doyumları üzerine bir araştırma. CBÜ Sos Bilim Derg . 2015;13:106-19.

36. Yoon E, Portman T. Critical issues of literature on counseling international students. J Multicult Couns Devel. 2004;32:33-44.

37. Ataca B, Berry JW. Psychological, sociocultural, and marital adaptation of Turkish immigrant couples in Canada. Int J Psychol. 2002;37:13-26.

38. Dion KK, Dion KL. Gender and cultural adaptation in immigrant families. J Soc Issues. 2001;57:511-21. 


\section{Ek 1. Sosyokültürel Uyum Ölçeği Türkçe Formu}

Aşağıda yaşam etkinliklerinizle ilgili zorluk yaşayabileceğiniz bir takım tanımlamalar bulunmaktadır. Bu ifadeler için size en uygun zorluk derecesini 0'dan (Hiç zor değil) 4 e (Olağanüstü zor) kadar bir değer belirterek işaretleyiniz.

\begin{tabular}{|c|c|c|c|c|c|c|}
\hline & & $\begin{array}{l}\text { Hiç Zor } \\
\text { Değil } \\
\end{array}$ & Biraz Zor & $\begin{array}{l}\text { Orta } \\
\text { Derece Zor }\end{array}$ & Çok Zor & $\begin{array}{l}\text { Olağanüstï } \\
\text { Zor }\end{array}$ \\
\hline 1. & Arkadaş edinmek & $\square$ & $\square$ & $\square$ & $\mathrm{b}$ & $\square$ \\
\hline 2. & Hoşuma giden yiyeceği bulmak & $\square$ & $\square$ & $\square$ & $\square$ & $\square$ \\
\hline 3. & Kurallara ve düzenlemelere uymak & $\square$ & $\square$ & $\square$ & $\square$ & $\square$ \\
\hline 4. & Yönetimdeki kişilerle anlaşmak & $\square$ & $\square$ & $\square$ & $\square$ & E \\
\hline 5. & $\begin{array}{l}\text { Kültürel olarak Türkiye'deki insanların bakış açısını } \\
\text { edinmek }\end{array}$ & $1]$ & $\nabla$ & $\square$ & 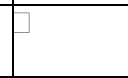 & 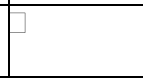 \\
\hline 6. & Ulaşım araçlarını kullanmak & $\square$ & $\square$ & $\square$ & $\square$ & $\square$ \\
\hline 7. & Bürokrasiyle başa çıkmak & $\theta$ & $\mathrm{b}$ & $\square$ & 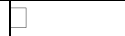 & $\square$ \\
\hline 8. & Türkiye'deki insanların değer yargılarını anlamak & $\square$ & $\square$ & $\square$ & $\square$ & $\square$ \\
\hline 9. & Kendimi anlaşıllır kılmak. & $\square$ & $\square$ & $\square$ & $\square$ & $\square$ \\
\hline 10. & Türkiye'deki insanların bakış açısından bakmak & $\square$ & $\square$ & $\square$ & $\square$ & $\square$ \\
\hline 11. & Alışverişe çıkmak & $\square$ & $\square$ & $\square$ & $\square$ & $\square$ \\
\hline 12. & Hoș olmayan bir kişiyle anlaşmak & $\square$ & $\square$ & $\square$ & 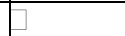 & 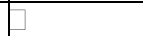 \\
\hline 13. & Şaka ve esprileri anlamak & $\square$ & $\square$ & $\square$ & $\square$ & $\square$ \\
\hline 14. & Kalacak yer bulabilmek & $\square$ & $\square$ & $\square$ & $\square$ & $\square$ \\
\hline 15. & Sosyal topluluklara katılmak & $\square$ & $\square$ & $\square$ & $\square$ & $\square$ \\
\hline 16. & Benimle uğraşan kişilerle baş edebilmek & $\square$ & $\square$ & $\square$ & $\square$ & $\square$ \\
\hline 17. & Değişik etnik gruplardan insanlarla iletişim kurmak & $\square$ & $\square$ & $\square$ & $\square$ & $\square$ \\
\hline 18. & Etnik ya da kültürel farklılıkları anlamak & $\square$ & $\square$ & $\square$ & $\square$ & $\square$ \\
\hline 19. & Yetersiz hizmetle baş edebilmek & $\square$ & $\square$ & $\square$ & $\square$ & $\square$ \\
\hline 20. & İbadet etmek & $\square$ & $\square$ & 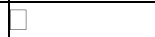 & $\square$ & 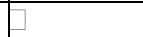 \\
\hline 21. & Karşı cinsle arkadaşlık kurmak & $\square$ & $\square$ & $\square$ & $\square$ & $\square$ \\
\hline 22. & Bir yere gidiş dönüş yolunu bulmak & $\square$ & $\square$ & $\square$ & $\square$ & $\square$ \\
\hline 23. & Türkiye'nin siyaset sistemini anlamak & $\square$ & $\square$ & $\square$ & $\square$ & $\square$ \\
\hline 24. & İklimle başa çıkmak & $\square$ & $\square$ & $\square$ & $\square$ & $\square$ \\
\hline 25. & Kendimle ilgili başkalarıyla konuşmak & $\square$ & $\square$ & $\square$ & $\square$ & $\square$ \\
\hline 26. & Türkiye'deki insanların dünya görüşünü anlamak & $\square$ & 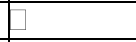 & $\square$ & $\square$ & 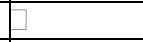 \\
\hline 27. & Aile ilişkileri & 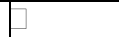 & $\mathrm{b}$ & $\mathrm{b}$ & 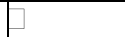 & Q \\
\hline 28. & Yaşam temposu & $\square$ & $\square$ & $\square$ & $\square$ & $\square$ \\
\hline 29. & Kültürler-arası bir soruna iki açıdan da bakabilmek & $\square$ & $\square$ & $\square$ & $\square$ & $\square$ \\
\hline
\end{tabular}

